\title{
GLL
}

Geomatics, Landmanagement and Landscape No. 4 • 2019, 219-230

\section{SILTING FORECAST OF THE PLANNED RETENTION RESERVOIRS WITHIN THE DRAINAGE SYSTEM IN ŁĄCZANY}

\author{
Bogusław Michalec, Mateusz Strutyński
}

\begin{abstract}
Summary
This paper presents the concept for the location of two dry water reservoirs designed to retain water led through the main ditch $(\mathrm{R})$ of the drainage system in Łączany. The purpose of the work is to develop a forecast for the reduction in the capacity of planned dry water reservoirs. Planned water reservoirs will allow increasing flood protection of drained areas. Based on geodetic measurements in the selected locations, the capacity of planned dry reservoirs was determined, amounting to 4.08 and 115.49 thousand $\mathrm{m}^{3}$, respectively for the $\mathrm{U}$ reservoir formed from the flood relief channel, and the $\mathrm{R}$ reservoir, located in the lower course of the $\mathrm{R}$ ditch. According to the developed forecast, applying the Gončarov formula, the $U$ reservoir would be $50 \%$ silted after 134 years, and the R reservoir would be $50 \%$ silted after 149 years. The forecast has been prepared using the method recommended by the guidelines, i.e. it was developed as for reservoirs with constant water damming (accumulation). TE values determined using the Churchill method were adopted in the silting forecast. The estimated forecast indicates a long service life of the reservoirs without the need for their desilting. However, the development of a detailed forecast would require a modification of the calculation methodology, taking into account the determination of the capacity of water reservoirs to retain bed load, typical of dry water reservoirs. In the absence of the method, determination of the service life cycle of water reservoirs can be developed as an estimate.
\end{abstract}

\section{Keywords}

drainage system $\bullet$ dry water reservoir $\bullet$ bed load transport $\bullet$ silting forecast

\section{Introduction}

The Łączany barrage on the Vistula (Wisła) river was built in 1955-1961, being one of the elements of the Upper Vistula Waterway. Its task is to enable navigation, water intake for the Skawina CHP Plant, as well as to enable a bridge crossing [Kisiel 2011]. In order to eliminate the negative effects of damming the Vistula waters on the areas adjacent to the water barrage, a drainage system was built. It consists of devices draining the adjoining areas, siphons for conducting small watercourses under the channel, 
embankment locks, pumping stations [Wpływ piętrzenia... 1987]. Excess infiltrating water is discharged via a drainage system to seven pumping stations [Instrukcja... 2010]. Five pumping stations are located on the left bank of the Vistula River, and four of them drain water from the main $\mathrm{R}$ ditch. This ditch is the main receiver of water flowing from the drainage system with gravity drainage to the lower station of the Eaczany barrage. In the period of elevated water levels in the Vistula, i.e. over $2.5 \mathrm{~m}$ above the average annual flow, the outflow via the $\mathrm{R}$ ditch is impossible due to the flooding of the shaft culvert of this ditch by the Vistula waters [Projekt melioracji... 1957]. In such conditions, the water drained by the $\mathrm{R}$ ditch is collected in the valley of this ditch behind the Vistula embankment, flooding the areas adjacent to the ditch. Avoiding such a situation is possible by constructing a pumping station, or creating a retention water reservoir. This latter, being a dry reservoir, during the high water periods of the Vistula would allow water to accumulate until the embankment culvert would allow the gravitational outflow of water to the river. A similar function can be performed by a dry water reservoir created in the relief channel [Michalec et al. 2013]. The relief channel was constructed in 1960, as a result of a design study, according to which a part of the water flowing through the $\mathrm{R}$ ditch could be directed to this channel through the culvert and discharged to the Zarzecze pumping station [Projekt melioracji... 1957]. The $\mathrm{R}$ ditch was connected to the relief channel by means of a concrete culvert DN 500 $\mathrm{mm}, 3.0 \mathrm{~m}$ long. The liquidation of this culvert, through its backfilling, took place in 1961 after the flood in 1960, as a result of which excess water from the R ditch flooded the area of the Łączany-Zarzecze housing estate [Drugi etap odwodnienia... 1962].

The drainage system of the Łączany barrage not only performs the function related to the elimination of the effects of damming the water in Vistula river via the Eaczany barrage, but is also used to protect areas located in the vicinity of the barrage from flooding. According to the Instrukcja... [2010], the hydrotechnical system eliminates the negative effects of damming the Vistula via water barriers under normal operating conditions, i.e. when the difference between the upper and the lower water levels is maintained on the barrage. Therefore, the implementation of dry water reservoirs can contribute to reducing the negative effects of flooding in areas drained by the system. The paper presents the concept for the location of two dry water reservoirs, retaining water led through the main $\mathrm{R}$ ditch of the drainage system in Łączany. The purpose of the work is to develop a forecast for the reduction of capacity of planned dry water reservoirs.

\section{Studied object}

The zone protected by the Łączany drainage system (Fig. 1) covers an area of over 24 $\mathrm{km}^{2}$. The main and longest drainage ditch is the $824 \mathrm{~m}$ long $\mathrm{R}$ ditch, which drains an area of over $13 \mathrm{~km}^{2}$. The area between the Vistula, the Spytkowski stream, and the Kasztelan pond is drained via the Kasztelan ditch. The waters of the Półwiański stream watershed are discharged directly to the Vistula, to the upper stage of the Łączany barrage. However, the waters of the Wilgoszcz stream watershed were originally discharged into the Półwiejski stream. As part of the works related to the construction of the drainage 
system, in order to limit the water inflow to the Zarzecze pumping station, the outflow direction of the Wilgoszcz stream was changed, directing it to the Małopolski canal [Koncepcja... 1986].

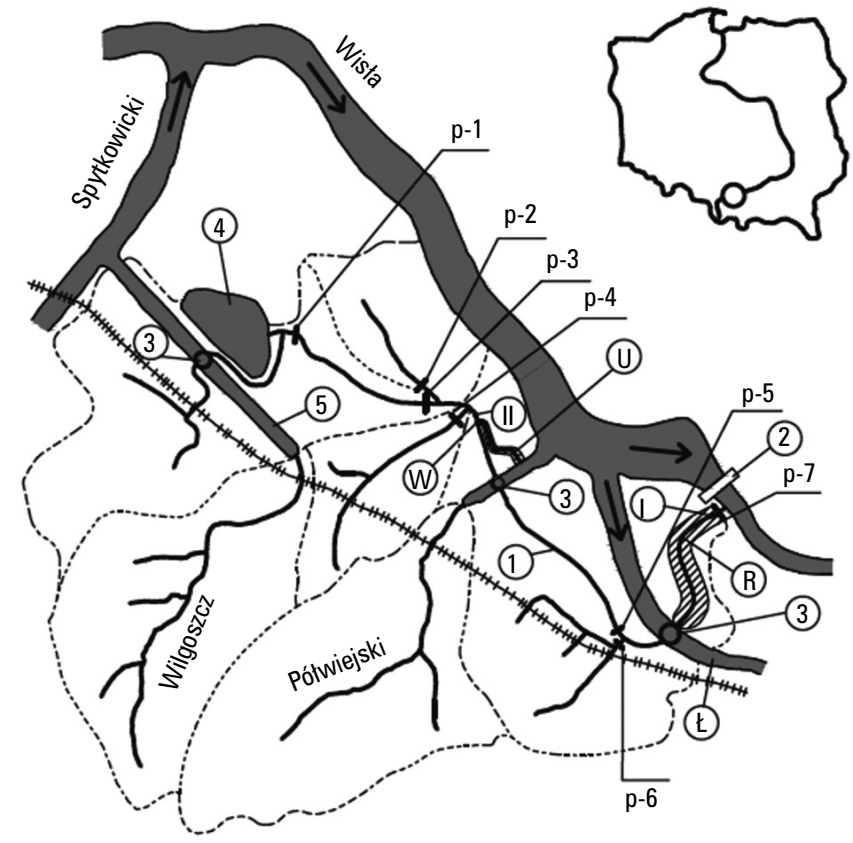

Source: Authors' own study

Fig. 1. Drainage system of the Łączany water barrage, where: 1 - R ditch, 2 - stopień Łączany barrage, 3 - siphons, 4 - Kasztelan pond, 5 - Małopolski canal, U - planned U reservoir, $\mathrm{R}$ - planned R reservoir, $€$ - Łączany-Skawina canal, I and II - sites of sediment samples' collection in the $\mathrm{R}$ ditch, $\mathrm{W}$ - water junction, $\mathrm{p}$-to p-7 - measurement cross-sections

\section{Research methodology}

As a result of site visits, the locations of two dry water reservoirs were adopted (Fig. 1). These reservoirs were located in such a way that they could collect water led through the main ditch $(\mathrm{R})$ of the drainage system. The first reservoir, marked with the symbol $\mathrm{R}$, was located in the outlet section of the $\mathrm{R}$ ditch between the Vistula embankment culvert $(\mathrm{km} 0+000$ of the R ditch) and the section at $1+450 \mathrm{~km}$ (Fig. 2a). The location of the second reservoir was adopted according to the concept proposed in the work by Michalec et al. [2013]. This reservoir (Fig. 2b), marked with the symbol U, was located on the section of the ditch, which is draining some of the water from the $\mathrm{R}$ ditch to the Zarzecze pumping station. At $\mathrm{km} 4+100$ of the $\mathrm{R}$ ditch there is a defunct water node, which as a result of the reconstruction proposed in the work by Michalec et al. [2013] 
would make it possible to direct a part of the flood waters of the $\mathrm{R}$ ditch to a water reservoir formed from the relief channel. The volume of the planned water reservoirs was calculated as the sum of partial volumes of reservoirs contained between two designated adjacent cross-sections, taking into account the distance between them. It was assumed that the planned dry water reservoir would be constructed without earthworks, i.e. while maintaining the existing shape of the ditch bed and areas adjacent to the ditch bed, i.e. maintaining the shape of the cross-section of the relief channel in the calculations of the capacity of the $U$ reservoir and the shape of the valley cross-section in the calculation of the capacity of the $\mathrm{R}$ reservoir.

Geodetic measurements of the areas covered by the designated location of the water reservoirs in the drainage system were carried out using the Topcon AT-G7 level and the Topcon 226 electronic total station. These measurements were carried out from September to November 2012 and from March to May 2013 in designated crosssections of planned dry water reservoirs. The cros-sections marked in figures 2, 3 and 4 made it possible to determine the initial capacity $\left(V_{p}\right)$ of these reservoirs.
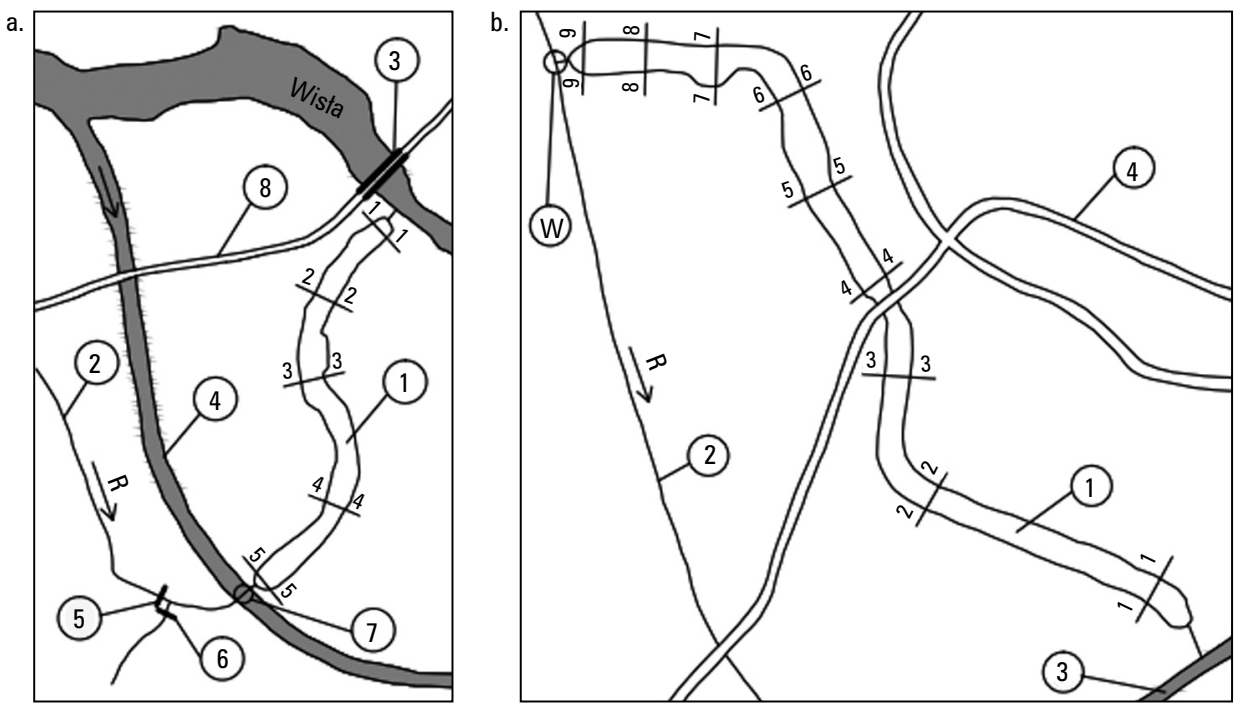

Source: Authors' own study

Fig. 2. Planned dry retention reservoirs of the Łączany barrage drainage system a. R reservoir, where: 1 - $\mathrm{R}$ reservoir, 2 - $\mathrm{R}$ ditch, 3 - Łączany water barrage, 4 - Łączany-Skawina canal, 5 - measurement cross-section p-5, 6 - measurement cross-section p-6, 7 - siphon of ditch R, 8 - road; b. U reservoir - where: 1 - U reservoir, 2 - R ditch, 3 - Półwiejski stream, 4 - road

Silting forecast of the planned water reservoirs was determined according to the guidelines developed by Wiśniewski and Kutrowski [1973]. According to the guidelines, the Gončarov formula was used as follows: 


$$
Z_{t}=V_{p}\left[1-\left(1-\frac{R_{1}}{V_{p}}\right)^{t}\right]
$$

where:

$Z_{t}$ - volume of deposits $\left[\mathrm{m}^{3}\right]$ after $t$ years,

$V_{p}$ - initial volume of the reservoir $\left[\mathrm{m}^{3}\right]$,

$R_{1}$ - volume of deposits after the first year of operation $\left[\mathrm{m}^{3}\right]$,

$t \quad-$ years of operation.

The volume of deposits after the first year of operation $\left(R_{1}\right)$ was calculated from the following formula:

where:

$$
R_{1}=\frac{\mathrm{TE} \cdot S}{\rho_{0}}
$$

$S$ - average annual sediment mass flowing into the reservoir $[t]$,

TE - reservoir's sediment trap efficiency [-],

$\rho_{0}-$ bulk weight of the sediment $\left[\mathrm{t} \cdot \mathrm{m}^{-3}\right]$.

The average annual mass of sediment flowing into the planned dry water reservoirs was adopted on the basis of calculations of transported sediment. These calculations were made for the catchment area of the $\mathrm{R}$ ditch based on the results of bathometric measurements, i.e. measurements of transported sediment concentration. These measurements were made in fourteen measurement series, in cross-sections of the $\mathrm{R}$ ditch and its tributaries. The location of the measurement cross-sections (see Fig. 1) was adopted in such a way that the transport calculations would take into account the intensity of sediment inflow from the lateral ditches feeding the $\mathrm{R}$ ditch. These measurements were made in the period from May 2015 to November 2016. The methodology of measurements and calculations as well as the results of calculations of the average annual sediment transport in the cross-sections of the $\mathrm{R}$ ditch was presented in the works of Michalec [2018a] and Michalec and Strutyński [2019].

The reservoir's ability to contain sediment (TE), according to the guidelines developed by Wiśniewski and Kutrowski [1973], should be determined from the Lopatin's nomograph. However, this nomograph may be used for reservoirs whose capacity factor $(\mathrm{C}-\mathrm{I})$ is greater than $1.5 \%$. The reservoir capacity ratio $(\mathrm{C}-\mathrm{I})$ is defined as the quotient of the reservoir's initial capacity $\left(V_{p}\right)$ and the sum of the average annual water inflow $(\Sigma S Q)$ thereto. As the studies of small water reservoirs with capacities smaller than 3.86 million $\mathrm{m}^{3}$ have shown, the use of this nomograph is not possible due to the value of the capacity factor less than $1.5 \%$, or it is burdened with a significant error [Michalec 2008]. The capacity of the planned reservoirs to contain sediment was determined with the application of Brune's method [1953], Brune's method in Heinemann's modification [1981], and Churchill's method [1948]. Brune's method was used because 
it is one of the most commonly applied in the forecasting of reservoir silting. Brune [1953] developed a nomograph for determining TE values based on tests of 41 water reservoirs in the United States of America. The median curve for normal ponded reservoir of this nomograph describes the relationship in the following form:

$$
\mathrm{TE}=100 \cdot\left(0,97^{0,19^{\log C-1}}\right)
$$

where $\mathrm{C}-\mathrm{I}$ is capacity inflow ratio.

Heinemann's modification of Brune's method [1981] was developed for small water reservoirs based on 20 reservoirs with a catchment area between 0.8 and $36.3 \mathrm{~km}^{2}$.

$$
\mathrm{TE}=-22+\frac{119.6 \mathrm{C}-\mathrm{I}}{0.012+1.02 \mathrm{C}-\mathrm{I}}
$$

where C - I is capacity inflow ratio as in formula (3).

The TE value was also determined using Churchill's method, as it facilitated obtaining satisfactory results in determining the capacity to retain debris of small water reservoirs with capacities between 22.57 thousand $\mathrm{m}^{3}$ and 3.86 million $\mathrm{m}^{3}$, studied by Michalec [2008]. The capacity to retain the debris [TE] according to Churchill [1948] is described by the following equation:

$$
\mathrm{TE}=100-\left(800 \cdot \mathrm{SI}^{-2}-12\right)
$$

where SI - sedimentation index - can be determined from the formula by Batuca and Jordaan [2000]:

$$
\mathrm{SI}=\frac{T_{R}}{V_{R}}
$$

where:

$T_{R}$ - water retention time in the water reservoir [s],

$\bar{V}_{R}$ - the average velocity of water flow through the reservoir $\left[f t \cdot s^{-1}=0,3048 \mathrm{~m} \cdot \mathrm{s}^{-1}\right]$.

As suggested by the United States Department - Soil Conservation Service (USDASCS), the reservoir's specific capacity to retain sediment should be reduced by $5 \%$ for sandy sediments and by $10 \%$ for mainly fine-grained sediments collected in dry reservoirs [Verstraeten and Poesen 2000]. Following this suggestion, the value of the reservoir's capacity to retain sediment was reduced by $10 \%$ in the calculation according to Brune's method [1953], and Brune's method in Heinemann's modification [1981]. In turn, the reservoir's capacity to retain sediment in the calculation applying Churchill's method was adopted without reducing its value, because as Borland (1971) stated, the data from semi-dry and dry reservoirs pertaining to TE values correspond well with TE values presented on the Churchill's nomograph. 
The volumetric density of sediments $\left(\rho_{0}\right)$ was determined on the basis of the results from the analyses of sediments sampled in the $\mathrm{R}$ ditch. Sampling locations are marked in Figure 1. Sample No. I was collected 200 meters below the junction on the R ditch in which the left-side lateral inflow to the $\mathrm{R}$ ditch (with measuring cross-section $\mathrm{p}-2$ ) connects to the $\mathrm{R}$ ditch below the measuring cross-section on the ditch $\mathrm{R}$, designated by the symbol p-3 (see Fig. 1). The sediment sample taken at this location made it possible to determine the volumetric density of sediments $\left(\rho_{0}\right)$ used in calculations of the volume of deposits after the first year of operation $\left(R_{1}\right)$, deposited in the planned $\mathrm{U}$ reservoir on the relief channel. In turn, based on the analysis of sediment sample No. II taken from the bed of the $\mathrm{R}$ ditch above section p-7 (see Fig. 1), the volumetric density of the sediments $\left(\rho_{0}\right)$ was determined, used in calculating the volume of deposits after the first year of operation $\left(\mathrm{R}_{1}\right)$ in the planned reservoir $\mathrm{R}$.

\section{Results}

Based on the results of geodetic measurements, cross-sections were developed through the existing valley of the lower section of the $\mathrm{R}$ ditch and the relief channel (see Fig. 2a and $2 b$ ).

On the basis of the nine cross-sections in the relief channel and the measured distances between them, the maximum capacity of the dry retention reservoir $U$ was calculated. The lowest left elevation of the left bank in the fifth cross-section was calculated as $214.89 \mathrm{~m}$ above sea level. It was assumed that the dry water reservoir would be created with a safe elevation of the reservoir's embankment crown, adopted at the level of $0.3 \mathrm{~m}$ above the ordinate of the water table accumulated in the relief channel. Thus, the ordinate of the water table accumulated in the $U$ reservoir was determined as $214.59 \mathrm{~m}$ a.s.l., and the capacity of this reservoir was calculated, amounting to 4.08 thousand $\mathrm{m}^{3}$. A dry retention reservoir $\mathrm{U}$, formed from the relief channel, would be separated by a road bridge dividing the reservoir into its upper and lower parts. The volume of the upper part of the $\mathrm{U}$ reservoir is $1100 \mathrm{~m}^{3}$, and the volume of the lower part of the $U$ reservoir is $2980 \mathrm{~m}^{3}$.

The maximum volume of the dry water reservoir $\mathrm{R}$, located in the lower course of the $\mathrm{R}$ ditch, i.e. over a length of $1450 \mathrm{~m}$ of this ditch from the cross section at $0+000$ $\mathrm{km}$, was determined for the assumed maximum water level of $214.00 \mathrm{~m}$ above sea level. The calculated maximum capacity of the $\mathrm{R}$ reservoir is 115.49 thousand $\mathrm{m}^{3}$. During the planning works, it was also assumed that the safe elevation of the reservoir's embankment crown, i.e. the adopted $0.3 \mathrm{~m}$ above the ordinate of the water table accumulated in the reservoir, would be maintained in this reservoir.

In order to determine the capacity ratio (C-I), the average annual water flow $(S Q)$ inflowing to the planned reservoirs was determined. This flow for the reservoir $U$ was determined at $30 \%$ of the flow rate being the sum of flow rates in cross-sections p- $2, \mathrm{p}-3$ and $\mathrm{p}-4$, determined as a result of tests carried out by Michalec [2018b] and amounting to $0.036,0.011$, and $0.015 \mathrm{~m}^{3} \cdot \mathrm{s}^{-1}$, respectively. In turn, the average annual water flow (SQ), inflowing to the planned R reservoir, determined in the work of Michalec [2018b], 
is $0.109 \mathrm{~m}^{3} \cdot \mathrm{s}^{-1}$. The C-I ratio was calculated for the average annual flow (SQ), while the sedimentation index $(S I)$ was calculated for the flood inflow $\left(Q_{w}\right)$ to the reservoirs, corresponding to the maximum capacity of a given section of the $\mathrm{R}$ ditch. Therefore, the flood discharge was assumed for the dry retention reservoir $\mathrm{U}\left(Q_{w}\right)$, specified in the work of Michalec et al. [2013], amounting to $2.13 \mathrm{~m}^{3} \cdot \mathrm{s}^{-1}$ and being the difference of the maximum flow rate $\left(Q_{4}=3.19 \mathrm{~m}^{3} \cdot \mathrm{s}^{-1}\right)$ and the flow through the passage culvert $\left(Q_{p}=1.06\right.$ $\mathrm{m}^{3} \cdot \mathrm{s}^{-1}$ ). The maximum flow $Q_{4}$ determines the maximum flow capacity in the $\mathrm{R}$ ditch on the water supply section to the water node (marked as W in Fig. 1) directing part of this flow to the $\mathrm{U}$ reservoir, formed from the relief channel. The flow through the culvert located on the $\mathrm{R}$ ditch below the water junction reduces the capacity of the $\mathrm{R}$ ditch on this section, hence it was assumed that the $Q_{w}$ flow should be directed to the relief channel, the flow rate of which is the difference between these two flows. Assuming a constant water supply of $Q=2.13 \mathrm{~m}^{3} \cdot \mathrm{s}^{-1}$ to the retention reservoir with a total capacity of 4080 $\mathrm{m}^{3}$, its filling time is less than 32 minutes. This filling time does not take into account the operation of the Zarzecze pumping station, whose maximum pump capacity is 0.19 $\mathrm{m}^{3} \cdot \mathrm{s}^{-1}$, which is the total maximum capacity of two mono-block centrifugal pumps of type 200HL-24, with a capacity of $0.095 \mathrm{~m}^{3} \cdot \mathrm{s}^{-1}$ [Instrukcja... 2010].

For the dry retention reservoir $\mathrm{R}$, the flood flow $\left(Q_{w}\right)$ was assumed, determined for the section of the $\mathrm{R}$ ditch from the Vistula embankment lock, i.e. from $\mathrm{km} 0+000$ to the inlet to the planned reservoir, that is to the section at $\mathrm{km} 1+150$, which corresponds to the maximum capacity of the $\mathrm{R}$ ditch on this section, and amounts to 10.37 $\mathrm{m}^{3} \cdot \mathrm{s}^{-1}$ [Michalec 2018b]. The sedimentation index was calculated according to the formula (6), in which the $Q_{w}$ flow was introduced to replace the $S Q$ flow. The results of the calculations are presented in Table 1 . Assuming a constant water supply to the $\mathrm{R}$ reservoir, amounting to $10.37 \mathrm{~m}^{3} \cdot \mathrm{s}^{-1}$, its filling time will be 3 hours and 5 minutes. If the reservoir is filled with water and the Vistula embankment lock is closed, it will be necessary to use a set of portable pumps for transferring water to the Vistula.

Table 1. Capacity ratio (C-I) and sedimentation index (SI) of the planned dry retention reservoirs

\begin{tabular}{|c|c|c|c|c|c|c|}
\hline Reservoir & $\begin{array}{c}\text { Average } \\
\text { flow SQ } \\
{\left[\mathrm{m}^{3} \cdot \mathrm{s}^{-1}\right]}\end{array}$ & $\begin{array}{c}\text { Initial } \\
\text { reservoir } \\
\text { volume } \\
V_{p}\left[\mathrm{~m}^{3}\right]\end{array}$ & $\mathrm{C}-\mathrm{I}[-]$ & $\begin{array}{c}\text { Water retention } \\
\text { time in the } \\
\text { reservoir } \\
T_{R}[\mathrm{~s}]\end{array}$ & $\begin{array}{c}\text { Average flow } \\
\text { velocity through } \\
\text { the reservoir } \\
\bar{V}_{R}\left[f t \cdot \mathrm{s}^{-1}\right]^{*}\end{array}$ & $\begin{array}{c}\text { SI } \\
{\left[s^{2} \cdot f t^{-1}\right]^{*}}\end{array}$ \\
\hline $\mathrm{U}$ & 0.019 & 4080 & 0.00696 & 219355 & 0.00815 & $2.69 \cdot 10^{7}$ \\
\hline $\mathrm{R}$ & 0.109 & 115490 & 0.0336 & 1059541 & 0.00449 & $2.36 \cdot 10^{8}$ \\
\hline
\end{tabular}

* Due to the application of Churchill's formula in its original format in the present work, which uses US units of measure, appropriate non-SI units were upheld

Table 2 presents the ability to contain sediment (TE) of the planned dry retention reservoirs, calculated using Brune's method [1953], Brune's method in Heinemann's modification [1981], and Churchill's method [1948]. 
Table 2. Ability to contain sediment (TE) of the planned dry retention reservoirs

\begin{tabular}{|c|c|c|c|}
\hline \multirow{2}{*}{ Reservoir } & \multicolumn{3}{|c|}{ TE [\%] } \\
\cline { 2 - 4 } & $\begin{array}{c}\text { According } \\
\text { to Brune }\end{array}$ & $\begin{array}{c}\text { According to Brune } \\
\text { in Heinemann's modification }\end{array}$ & $\begin{array}{c}\text { According } \\
\text { to Churchill }\end{array}$ \\
\hline $\mathrm{U}$ & 33.4 & 21.6 & 85.9 \\
\hline $\mathrm{R}$ & 70.3 & 64.8 & 95.1 \\
\hline
\end{tabular}

The reduction of TE values determined using Brune's method and Brune's method in Heinemann modification, as suggested by USDA-SCS, will lead to the TE value for the $U$ reservoir at the level of 23.4 and $11.6 \%$, respectively; and for the R reservoir, 60.3 and $54.8 \%$, respectively. In the silting forecast, TE values determined using Churchill's method were adopted, thus obtaining the least-favourable calculation variant due to the so-called service life of the analysed reservoirs.

The average annual mass of sediment flowing into the planned dry water reservoirs was determined on the basis of the results of the research presented in the paper by Michalec [2018a], concerning the determination of sediment delivery ratio (SDR) to the measurement cross-sections shown in Figure 1. The amount of sediment entering the water junction ( $\mathrm{W}$ in Fig. 1) was determined as the sum of the calculated average annual sediment transport in cross-sections p-2, p-3 and p-4, amounting to 72.50, 10.10 and $36.32 \mathrm{t} \cdot$ year $^{-1}$, respectively. Thus, the average sediment mass entering the $\mathrm{W}$ water junction is $118.92 \mathrm{t} \cdot$ year $^{-1}$. The following sediment separation was also adopted, as for the water distribution in this junction: $30 \%$ of the transported sediment mass flows into the relief channel ( $\mathrm{U}$ reservoir), and the remaining drains off through the $\mathrm{R}$ ditch. Hence, the average annual sediment mass flowing into the $U$ reservoir is $35.68 \mathrm{t} \cdot \mathrm{year}^{-1}$. Whereas the average annual mass of sediment flowing into the $\mathrm{R}$ reservoir was adopted from the calculations of sediment transport, computed in cross-section p-7 (983.08 t . year $^{-1}$ ) [Michalec 2018a] and reduced by the outflow at the $\mathrm{W}$ junction to the $\mathrm{U}$ reservoir $\left(35.68 \mathrm{t} \cdot\right.$ year $\left.^{-1}\right)$. Therefore, the average annual mass of sediment entering the $\mathrm{R}$ reservoir is $947.40 \mathrm{t} \cdot$ year $^{-1}$.

Table 3. Volume of sediment deposition after the first year of operation $\left(\mathrm{R}_{1}\right)$ of the planned dry retention reservoirs

\begin{tabular}{|c|c|c|c|c|}
\hline Reservoir & $\begin{array}{c}\text { Average annual } \\
\text { mass of sediment } \\
\text { entering the reservoir } \\
S[\mathrm{t}]\end{array}$ & $\begin{array}{c}\text { Sediment } \\
\text { volumetric } \\
\text { density } \\
\rho_{0}\left[\mathbf{t} \cdot \mathbf{m}^{-3}\right]\end{array}$ & $\begin{array}{c}\text { Reservoir's } \\
\text { ability to contain } \\
\text { sediment } \\
\text { TE }[\%]\end{array}$ & $\begin{array}{c}\text { Volume of sediment } \\
\text { deposition after the first } \\
\text { year of operation } \\
\mathrm{R}_{1}\left[\mathbf{m}^{3}\right]\end{array}$ \\
\hline $\mathrm{U}$ & 35.68 & 1.45 & 85.9 & 21.1 \\
\hline $\mathrm{R}$ & 983.08 & 1.73 & 95.1 & 211.2 \\
\hline
\end{tabular}


The specified average annual sediment transport volume and sediment volumetric density determined on the basis of the analysis of sediment samples (I and II) taken from the bed of the ditch, as well as the determined TE values according to Churchill, allowed the calculation of the volume of sediment deposition after the first year of operation $\left(\mathrm{R}_{1}\right)$ from the formula (2). The results are given in Table 3.

Figure 3 presents silting forecast of the planned dry retention reservoirs in Łączany drainage system.
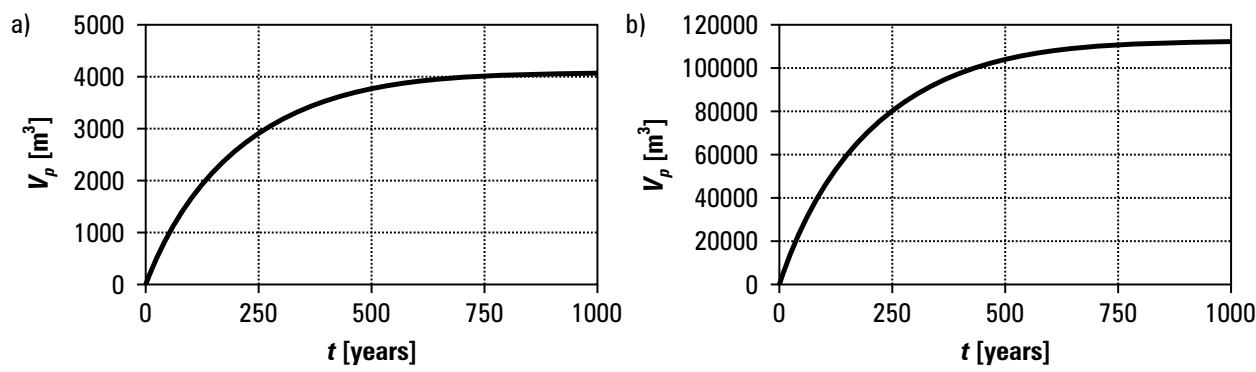

Source: Authors' own study

Fig. 3. Silting forecast of the planned dry retention reservoirs: a. U reservoir, b. R reservoir

\section{Conclusions}

The methods of determining the reservoir's ability to contain sediment, cited in international specialist literature, relate to reservoirs that permanently accumulate water. In the case of semi-dry and dry reservoirs, the data from the obtained tests are supplemented only by the nomographs developed on the basis of testing the reservoirs permanently filling the water. Thus, based on these data, no methods were established to determine TE, and no methodology for forecasting the silting of dry water reservoirs was developed. Using the silting forecast of water reservoirs that permanently accumulate water, the service life of planned dry water reservoirs in the Łączany drainage system was estimated. The U reservoir (see Fig. $2 \mathrm{~b}$ ) would be silted in $50 \%$ after 134 years, and the $\mathrm{R}$ reservoir (see Fig. 2a) would be silted in 50\% after 149 years, if both reservoirs were constantly accumulating water. Forecast using Gončarov formula does not take into account the periodic accumulation of water in the reservoir. However, the results of this forecast can be considered for dry water reservoirs only as a guide for estimating the service life of these reservoirs. In this estimation of the viability of the analysed water reservoirs, TE was determined using Churchill's method. High TE values, close to $100 \%$, mean almost complete depositing of sediment flowing into the canopy of the reservoirs. If the silting forecast assumes TE values determined by Heinemann's modification of Brune's method, the estimated lifetime of the planned reservoirs would be several times higher than the one computed. Such a long forecasted silting period 
results from the low intensity of erosion processes in the basins of the drainage system, and the relatively small intensity of the average annual sediment transport, despite the fact that the calculated values of the C-I capacity ratio of the analysed reservoirs are typical for small water reservoirs, characterized by an intensive silting process.

The estimated forecast indicates a long service life of the reservoirs without the need for desilting. However, developing a detailed forecast would require modifying the calculation methodology. To achieve this, it would necessary to have a flood wave hydrograph, as well as a method for determining the reservoir's ability to contain sediment, specifically for dry water reservoirs. Due to the lack of such method, the determination of the service life of water reservoirs can be developed as an estimate.

\section{References}

Batuca G.D., Jordaan M.J. Jr. 2000. Silting and Desilting of Reservoirs. A.A. Balkema. Rotterdam, Netherlands, 353.

Borland W.M. 1971. Reservoir sedimentation. [In:] River mechanics, vol. II. Ed. H.W. Shen. Fort Collins, CO, Colorado State University, 29.1-29.38.

Brune G.M. 1953. Trap efficiency of reservoirs. Transactions of the American Geophysical Union, 34, 407-418.

Churchill M.A. 1948. Discussion of analyses and use of reservoir sedimentation data by L.C. Gottschalk. Proceedings of the federal interagency sedimentation conference. Denver, Colorado, Washington, DC. US Geological Survey, 139-140.

Drugi etap odwodnienia wsi Łączany. Pompownia Zarzecze. CBSiPBW Hydroprojekt, maszynopis. Warszawa, 1962.

Heinemann H.G. 1981. A new sediment trap efficiency curve for small reservoirs. Water Resources Bulletin, 17, 825-830.

Instrukcja utrzymania i eksploatacji pompowi Zarzecze. 2010. Część I. Hydrologiczno-technologiczna. Pracownia Projektowa Forex s.c.

Kisiel A. 2011. Modernizacja dolnego stanowiska stopnia wodnego Łączany na rzece Wiśle w 2001 roku. Gospodarka Wodna, 11, 463-471.

Koncepcja. Stopień Wodny Łączany. 1986. Pompownia odwadniająca na rowie „R”. Ustalenie wydatku instalowanego. Opis techniczny. CBSiPBW Hydroprojekt, Warszawa.

Michalec B. 2008. Ocena intensywności procesu zamulania małych zbiorników wodnych w dorzeczu Górnej Wisły. Zeszyty Naukowe Uniwersytetu Rolniczego w Krakowie, 451, ser. Rozprawy, 328.

Michalec B. 2018a. Determination of sediment delivery ratio in draining system. Acta Scientiarum Polonorum, ser. Formatio Circumiectus, 17 (4), 131-141.

Michalec B. 2018b. Ocena przepustowości rowu głównego R systemu odwadniającego Łączany. Infrastruktura i Ekologia Terenów Wiejskich, III/1, 771-785.

Michalec B., Strutyński M. 2019. Określenie warunków przepływu rumowiska unoszonego w systemie odwodnieniowym. Acta Scientiarum Polonorum, ser. Formatio Circumiectus (w druku).

Michalec B., Wałęga A., Cupak A. 2013. Retencja zbiornikowa w ochronie przeciwpowodziowej terenów systemu odwadniającego stopnia wodnego Łączany na Wiśle. Infrastruktura i Ekologia Terenów Wiejskich, 3/IV, 177-190.

Projekt melioracji doliny rzeki Wisły, obiekt Łączany. 1957. CBSiPBW Hydroprojekt, Warszawa. 
Verstraeten G., Poesen J. 2000. Estimating trap efficiency of small reservoirs and ponds: Methods and implications for the assessment of sediment yield. Progress in Physical Geography, 24, 2, 219-251.

Wiśniewski B., Kutrowski M. 1973. Budownictwo specjalne w zakresie gospodarki wodnej. Zbiorniki wodne. Prognozowanie zamulania. Wytyczne instruktażowe. Biuro Studiów i Projektów Budownictwa Wodnego „Hydroprojekt”, Warszawa.

Wpływ spiętrzenia Wisły w Łączanach na wody podziemne na terenach przyległych. 1987. Instytut Inżynierii Sanitarnej i Ochrony Środowiska. Politechnika Krakowska, maszynopis, Kraków.

Prof. dr hab. inż. Bogusław Michalec Uniwersytet Rolniczy w Krakowie Katedra Inżynierii Wodnej i Geotechniki e-mail: rmmichbo@cyf-kr.edu.pl ORCID: 0000-0002-0402-3416

Dr inż. Mateusz Strutyński Uniwersytet Rolniczy w Krakowie Katedra Inżynierii Wodnej i Geotechniki e-mail: mateusz.strutynski@urk.edu.pl ORCID: 0000-0002-7138-2101 